\title{
Sludge Phases as Cause of Higher Wear of Cutting Tools during Machining of Secondary AlSi12Cu1 Castings
}

Eva Tillová, Mária Chalupová, Lenka Kuchariková, Ivana Švecová, Juraj Belan

Faculty of Mechanical Engineering, University of Žilina, Univerzitná 8215/1, 01026 Žilina, Slovak Republic. E-mail: eva.tillova; maria.chalupova; lenka.kucharikova; ivana.svecova; juraj.belan@fstroj.uniza.sk

Present work is focused to determine the cause of higher wear of castings made of secondary (recycled) AlSi12Cu1 cast alloy after switching supplier and the morphological evolution of Fe-rich phases has been documented. As recycling of Al-alloys becomes more common, sludge will be a problem of increasing importance due to the concentration of $\mathrm{Fe}, \mathrm{Mn}$ and $\mathrm{Cr}$ in the scrap cycle. The tendency of $\mathrm{Al}$-Si-Cu alloys to form sludge $\mathrm{Fe}$-rich particles can be predicted by the sludge factor (SF) equation, which represents an attempt to gather the combined effects of $\mathrm{Fe}$, Mn and $\mathrm{Cr}$. Sludge phases are hard and brittle phases which can compromise the machining operations, with a considerable effect on the cutting tool life, and even more degrade the mechanical and physical properties of the component. For study and identification of intermetallic phases' was utilized standard etching (Dix-Keller, $\mathrm{H}_{2} \mathrm{SO}_{4}$ ) and for element composition was used X-ray analysis. The results show that coarse sludge Fe-rich phases appear in the alloy with 0.945 wt. \% Fe combined with higher content of $\mathrm{Cr}$, while the Chinese script or needlelike Fe-rich phases appear combined with $\mathrm{Mn}$. At the same time, a higher sludge factor was calculated and the ratio between the amount of $\mathrm{Fe}$ and $\mathrm{Mn}$ was not respected.

Keywords: Al-Si cast alloy, secondary alloys, Fe-rich phases, sludge phases, microstructure.

\section{Introduction}

Recycling play a key role on saving of natural resources and on reducing pollution. The recycling of aluminium alloys is cost-effective, since it reduces the material cost and creates a considerable energy-saving. The use of recycled Al-alloys (usually called secondary) has improved in recent years and a further increase is expected, also because of their comparable mechanical properties with primary aluminium alloys (Fig. 1) [1-2]. During the production of secondary aluminium alloys, the scrap are mixed regardless of their specific chemical composition, and then master alloys or pure elements are added to the molten metal. Furthermore, certain impurity elements are either difficult or expensive to remove, and their role in mechanical properties can be important. Due to the presence of these additional trace elements, a number of complex intermetallic phases can therefore form in multicomponent Al-Si alloys. Mechanical and physical properties of alloys and castings are strongly related to sizes, morphologies and distribution of these intermetallic phases, which are in turn a function of alloy composition and cooling rate [3-4].

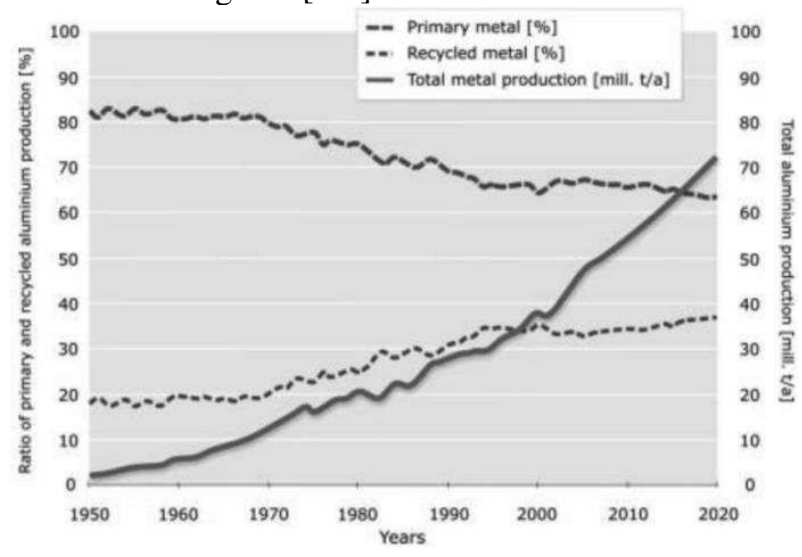

Fig. 1 Total aluminium production [1, 5]
At present the European Standard specifies the chemical composition of 43 aluminium alloys, without any distinction between alloys produced from ore (primary alloys) and recycled aluminium, produced by remelting scrap (secondary alloys). The difficulty in recycling cast alloys is one of tolerance, which is the ability of an alloy to absorb different grades of scrap during its manufacture, rather than requiring the use of primary metal. The tolerance limit of most foundry aluminium alloys is low, especially for the alloys commonly used in sand and gravity casting [4].

Depending on the purity of the base material, the AlSi foundry alloys contain varying amounts of impurity elements. Iron, manganese, copper and chromium correspond to typical impurities elements in secondary Al-Si$\mathrm{Cu}$ alloys. Copper substantially improves strength and hardness in the as-cast and heat treated conditions. It also improves the machinability of alloys by increasing matrix hardness, making it easier to generate small cutting chips and fine machined finishes. Moreover, this element generally reduces the corrosion resistance of aluminium alloys and in specific compositions and material conditions increases stress-corrosion susceptibility [6].

The most common impurity element is iron, stemming from impurities in bauxite ore and from contamination of scrap aluminium with ferrous metal. Since Fe has a very low solubility in aluminium, it forms a variety of intermetallic compounds with $\mathrm{Al}, \mathrm{Si}$ and other elements, which have a detrimental effect on the mechanical properties [79]. Fe cannot readily be removed from molten aluminium by conventional foundry treatment, thus dilution seems to be the only practical, although uneconomic, method to reduce its content in the alloy. In Al-Si cast alloys the Fe compounds crystallize as monoclinic $\beta-\mathrm{Al}_{5} \mathrm{FeSi}$ phase during the solidification, even at low Fe content in the melt. These plate-like phases, which appear as needles in the microstructure, act as stress raisers with a general reduction of the plastic properties of the cast alloy [7-12]. 
Furthermore, the $\mathrm{Al}_{5} \mathrm{FeSi}$ phases block feeding channels earlier due their needle-like morphology, and cause feeding problems and casting porosity [13]. The Fe-platelets are usually potential sites for crack initiation, where eventual breakup failure occurs too [7].

Although efforts are made to keep Fe content as low as economically possible in sand and gravity casting alloys, specifications normally permit considerably more iron. The Al-Fe-Si eutectic composition occurs at about 0.8 wt. \% Fe. A highest $\mathrm{Fe}$ content reduces the solution potential of the molten Al-alloy for the steel components of the casting machine and die, and consequently helps to prevent or alleviate the die-soldering [1, 2, 13].

Manganese and Chromium are present in secondary aluminium alloys as impurity elements, due to the scrap recycling process. However, they also have a beneficial effect in Al-Si cast alloy. Single or in combination, they can neutralize the detrimental effect of the $\beta-\mathrm{Al}_{5} \mathrm{FeSi}$ phase by modifying the plate-like morphology and type of phase to a less harmful body centred cubic crystal $\alpha$ $\mathrm{Al}(\mathrm{Fe}, \mathrm{Mn}, \mathrm{Cr}) \mathrm{Si}$, which may appear as Chinese script, star-like or polyhedral morphology. It is reported that if the Fe content exceeds 0.45 wt. $\%$, it is desirable to have $\mathrm{Mn}$ present in an amount equal to one half of the $\mathrm{Fe}[6$, $13,14,15]$.

Modification of Fe-rich phases with $\mathrm{Mn}$ and $\mathrm{Cr}$ addition has also some disadvantages [16], since they increase the total volume of Fe-rich particles. The complex of intermetallic phases, like $\alpha$-phases, can form as primary phases, which may appear as Chinese script, star-like or

polyhedral morphology. They have a high specific gravity and tend to segregate to the bottom of molten alloy and holding furnaces; such primary particles are generally called "sludge". When sludge phases are entrained into castings, they decrease the alloy's fluidity and appear as hard inclusions, which can compromise the machining operations and even more degrade the mechanical and physical properties of the component. The problem of sludge formation is often experienced in Al-foundries; especially in the die-casting sector where, in order to preserve the die and the tools, the holding and casting temperatures are typical lower than in the other foundry processes [4]. The formation of sludge particles may also encourage the die-soldering, even if the Al-Si alloys commonly used in HPDC allowed a high Fe content in order to prevent or alleviate this problem. Since sludge particles are composed mainly of $\mathrm{Fe}$ - and $\mathrm{Mn}$-rich compounds, their formation as primary phases causes a depletion of Fe and $\mathrm{Mn}$ in the melt $[4,6,13]$.

Several empirical formulas have been developed in order to predict whether a given alloy composition is likely to cause Fe-rich intermetallic compounds to be formed and to segregate. Based on the $\mathrm{Fe}, \mathrm{Mn}$ and $\mathrm{Cr}$ content in the alloy, a "sludge factor (SF)" is calculated (also referred as "iron equivalent value (IEV)", or "sludging factor", or "segregation factor", or "sedimentation factor"). This factor is matched to a suggested minimum holding temperature above which sludge formation would be minimized. The first sludge equation might be developed by Glaisher (1951) using the following formula $[4,13]$ :

$$
S F=(1 \times w t . \% \mathrm{Fe})+(1.5 \times w t . \% \mathrm{Mn})
$$

In order to calculate the sludge factor when the $\mathrm{Cr}$ content was considered, the SF was implemented as follows:

$$
S F=(1 \times w t . \% \mathrm{Fe})+(1.5 \times w t . \% \mathrm{Mn})+(2 \times w t . \% \mathrm{Cr})
$$

Parallel to this, another sludge factor formula was developed and first published by Dunn $(1965)[13,17]$ :

$$
S F=(1 \times w t . \% F e)+(2 \times w t . \% M n)+(3 \times w t . \% C r)
$$

Sludge factor (3) is currently the most widespread and accepted, since Gobrecht (1975) [4, 18] and Jorstad (1986) [4, 19] demonstrated that it well describes the sludge particles segregation in the holding furnace. A common foundry rule is to keep the SF under $1.7-1.8$.

The sludge factor may thus vary strongly depending on the chemical composition of the alloy; the higher the $\mathrm{SF}$, the higher the amount of sludge present in the microstructure [14, 20].

Presented paper is focused on concrete application of secondary aluminium alloys. It describes negative occurrence of sludge phases in castings with higher iron content. At the same time, it is an example of cooperation between the university and practice.

\section{Experimental}

The secondary (recycled) cast alloy AlSi12Cu1 (EN AC 47 000) [21] is used to produce castings for washing machines (Fig. 2). Castings are machined to final shape by customer. Standard casts were labelled as CPA. After the change of supplier (casts marked as CPB), the customer noticed a problem in machining these castings, namely excessive wear of the cutting tools. The customer requested metallographic analysis of the castings in order to determine the possible cause of higher tool wear. Metallographic comparison of original castings (CPA) and castings from new supplier (CPB) was compared. AlSi12Cu1 is a eutectic alloy with excellent foundry properties and high resistance to thermal cracks, which is designed for thin-walled castings.

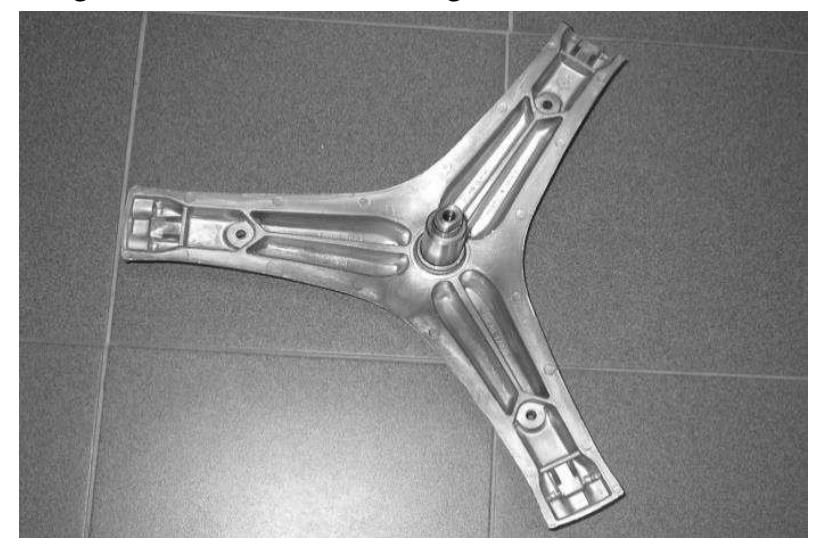

Fig. 2 Al-casting delivered for analysis 
The presence of eutectics gives these alloys a high self-absorbency, decreasing their linear shrinkage and the tendency to heat cracking. The chemical composition of experimental castings CPA and CPB (determined by spectrometry SPECTROMAX) and the chemical composition tolerance limits of the AlSi12Cu1 cast alloy (the base EN AC-47000 alloy - Standard EN 1706:2010) [20, 21] are listed in Table 1.

Tab. 1 Chemical composition of the experimental castings (wt. \%) and the composition limits of the EN AC-AlSi12Cu1 alloy (EN AC-47000) reported according to the EN standard 1706:2010

\begin{tabular}{|l|l|l|l|l|l|l|l|l|l|l|l|l|}
\hline & $\mathrm{Si}$ & $\mathrm{Mn}$ & $\mathrm{Fe}$ & $\mathrm{Cu}$ & $\mathrm{Mg}$ & $\mathrm{Cr}$ & $\mathrm{Ni}$ & $\mathrm{Zn}$ & $\mathrm{Pb}$ & $\mathrm{Sn}$ & $\mathrm{Ti}$ & $\mathrm{Al}$ \\
\hline Casting CPA & 12.5 & 0.245 & 0.622 & 0.85 & 0.347 & 0.023 & 0.04 & 0.42 & 0.055 & 0.01 & 0.026 & ball \\
\hline Casting CPB & 12.3 & 0.320 & 0.945 & 0.80 & 0.355 & 0.095 & 0.03 & 0.43 & 0.045 & 0.01 & 0.030 & ball \\
\hline EN AC 47000 & $10.5-$ & $0.05-$ & max. & max. & max. & max. & max. & max. & max. & max. & max. & ball \\
& 13.5 & 0.55 & 0.7 & 0.9 & 0.35 & 0.10 & 0.30 & 0.55 & 0.20 & 0.10 & 0.15 & \\
\hline
\end{tabular}

The microstructure of experimental castings was studied using an optical microscope Neophot 32 and scanning electron microscope (SEM) VEGA LMU II linked to the energy dispersive X-ray spectroscopy (EDX analyser Brucker Quantax). Experimental specimens were taken by cutting with a Micron 3000 automatic saw with cooling to avoid deformation of the microstructure or heat generated. After cutting, the specimens for microscopic analysis by optical and electron microscopy were prepared by standard metallographic procedures (hot preparation in bakelite, wet ground on SiC papers, DP polished with $3 \mu \mathrm{m}$ diamond pastes, finally polished with commercial fine silica slurry STRUERS OP-U and etched by DixKeller and $\mathrm{H}_{2} \mathrm{SO}_{4}\left(\mathrm{H}_{2} \mathrm{SO}_{4}\right.$ is etching to highlight the $\mathrm{Fe}$ phases present). Metallographic evaluation was performed first on non-etched samples and then in etched state. The quantitative analysis of sludge Fe-rich intermetallic phases was carried out using a NEOPHOT 32 light microscope equipped with a computer running NIS Element 4.0 image analyser software [22-24]. In order to minimize statistical errors in the determinations, $10 \mathrm{mi}$ crographs were assessed; a relative error of less than 0.05 was sought.

Hardness measurement was performed by a Brinell hardness tester with the load of $62.5 \mathrm{kp}, 2.5 \mathrm{~mm}$ diameter ball and the dwell time of $15 \mathrm{~s}$ according to standard STN EN ISO 6506-1. The Brinell hardness (HBW) value at each state was obtained by the average of at least five measurements.

\section{Results}

Typical microstructures of both evaluated castings (CPA and CPB) are documented in Fig. 3 and Fig. 4. The microstructure consists of $\alpha$-phase ( $\alpha$-matrix), eutectic (Si-crystals in $\alpha$-phase) and various types of $\mathrm{Fe}$ - and $\mathrm{Cu}$ rich intermetallic phases.

The most important elements affecting the machinability of aluminum casting alloys are $\mathrm{Si}, \mathrm{Fe}, \mathrm{Cu}$, and $\mathrm{Mg}$. All these elements increase the alloy strength and hardness and therefore generally improve machinability [25]. However, Si, which mostly exists as primary or eutectic particles in hypereutectic alloys, is abrasive, consequently tends to reduce tool life and as a hard phase increases the wear resistance of experimental AlSi12Cu1 alloys. Silicon in both castings has the shape of small imperfectly rounded grains, respectively, shorter plates (needles) (Fig. 3 and Fig. 4). Due to the shape of the eutectic $\mathrm{Si}$, it can be concluded that the castings were not heat treated.

A fine, wellmodified eutectic $\mathrm{Si}$ is far less detrimental to tool life than the other hard intermetallic phases. Tool wear increases as Si-particle size increases and as the eutectic Si becomes coarse tool life begins to suffer. Si-particles, even well refined and well distributed ones, are even more detrimental to tool life, and large, unrefined silicon can be devastating for tool life. Detail of silicon particles was observed by SEM, and is documented in the Figs. 5a and 6a. As seen, the silicon in casting CPB is larger and thicker.

Iron combines with aluminium, silicon, and other elements to form a variety of hard, complex insoluble phases. In the CPA casting, large amounts of small Ferich phases were observed (Fig. 3 and Fig. 5). $\alpha$-Fe-rich phases $\left(\mathrm{Al}_{15} \mathrm{FeMn}_{3} \mathrm{Si}_{2}\right)$ with fine skeleton-like or Chinese script morphology predominate. Polyhedral and star-like phases were observed only sporadically.

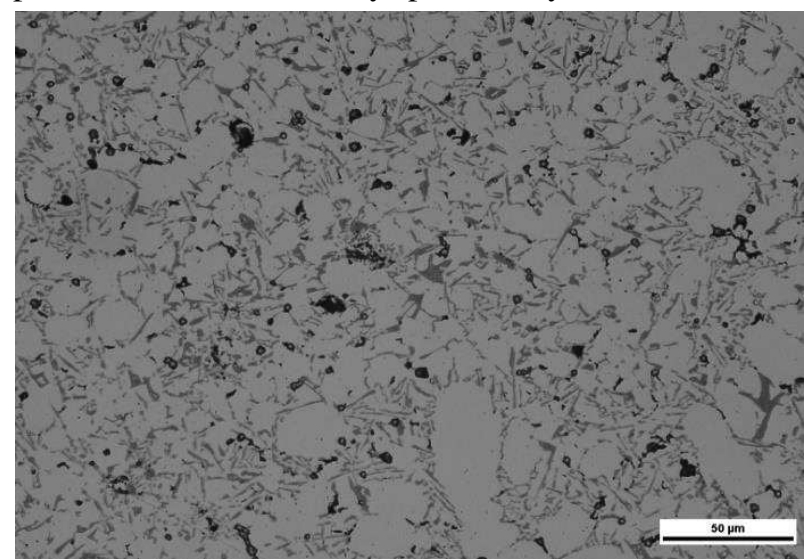

Fig. 3 Microstructure of CPA casting, etch. $\mathrm{H}_{2} \mathrm{SO}_{4}$

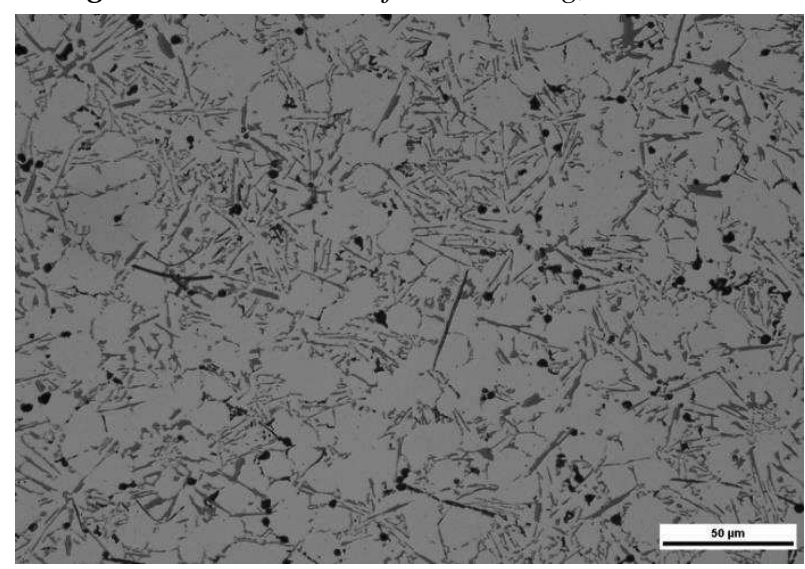

Fig. 4 Microstructure of $\mathrm{CPB}$ casting, etch. $\mathrm{H}_{2} \mathrm{SO}_{4}$ 
The amount of star-like particles increases with the level of $\mathrm{Fe}, \mathrm{Mn}$, and $\mathrm{Cr}$ in the casting $\mathrm{CPB}$ (Fig. 4 and Fig. 6), according to the SF value (Table 2). Moreover, a large number of plate/needle-like $\mathrm{Al}_{5} \mathrm{FeSi}$ phases were recognizable in casting $\mathrm{CPB}$, as a consequence of the higher $\mathrm{Fe} / \mathrm{Mn}$ ratio (3.265). The $\mathrm{Al}_{5} \mathrm{FeSi}$ phase forms in the interdendritic and intergranular regions as very thin platelets, which appear acicular or needle-like in a polished cross section. Here, the content of $\mathrm{Mn}$ and $\mathrm{Cr}$ was not sufficient to promote the formation of $\alpha$-Fe phases; therefore, a large number of plate-like (needles) Fe-phase coexisted with the star-like Fe-phases. It has been observed that low Fe/Mn ratio (2.824) leads Fe-rich phases to skeleton-like/Chinese script morphology, while higher $\mathrm{Fe} / \mathrm{Mn}$ ratio (3.265) in combination with higher $\mathrm{Cr}$ (just below the maximum allowable value $0.1 \mathrm{wt}$ \% $\mathrm{Cr}$ ) promotes the formation of polyhedral, star-like particles.

Copper is present primarily as very fine multi-phase eutectic-like deposits $\mathrm{Al}-\mathrm{Al}_{2} \mathrm{Cu}-\mathrm{Si}$ (blocky phase), which are difficult to see on an optical microscope.

The microstructure has been studied in detail at SEM. Morphology of silicon particles and Fe-phases are documented in Fig. 5a and Fig. 6a. Observation with the BSE (Back Scattered Electron) makes possible to highlight the Fe-phase (bright phases) and compare its amount in the individual castings. Comparison of distributions of the star-like Fe-phases in the microstructures of casting CPA and CPB can be seen in Figs. 5b, 6b. It is obvious that casting $\mathrm{CPB}$ with the higher content of iron contains more star-like Fe-phases.

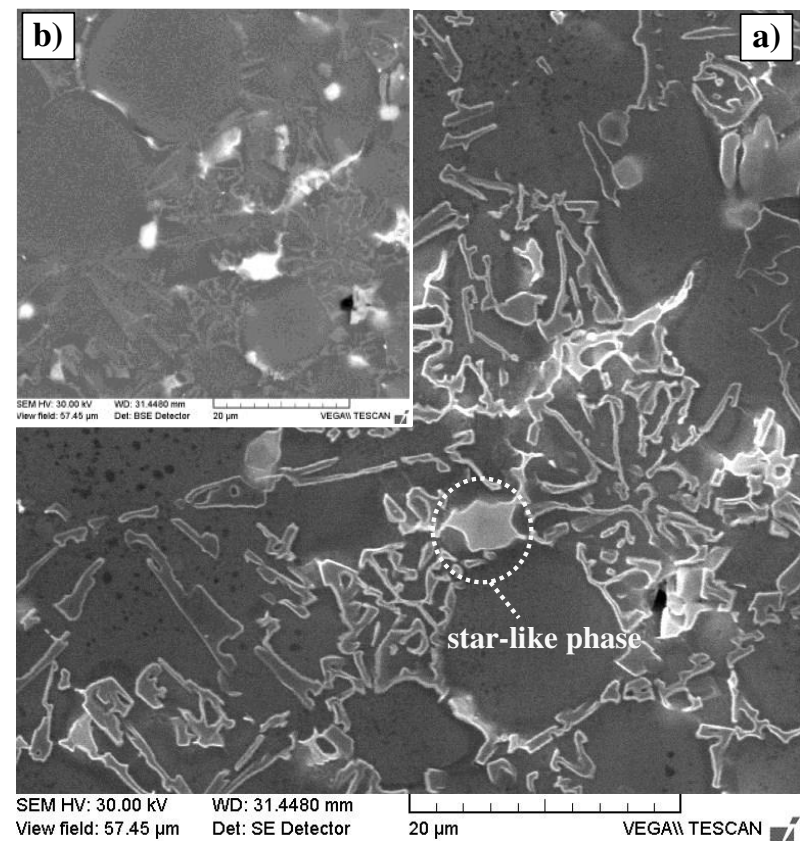

Fig. 5 Microstructure of CPA casting, SEM: a) detail of $\mathrm{Fe}$-phases, etch. Dix-Keller; b) distribution of $\mathrm{Fe}$ phases, BSE

The polyhedral and star-like Fe-phases may be sludge particles (Fig. 7) [4, 13, 14]. Sludge particles are $\mathrm{Fe} / \mathrm{Mn} / \mathrm{Cr}$ - containing phases. Shabestari [9] reported that the stoichiometry of sludge particles are $\alpha$ $\mathrm{Al}_{12}(\mathrm{Fe}, \mathrm{Mn}, \mathrm{Cr})_{3} \mathrm{Si}_{2}$; while Mondolfo [26] described these compounds as a solid solution of $\mathrm{Fe}$ and $\mathrm{Cr}$ in the $\mathrm{Al}_{15} \mathrm{Mn}_{3} \mathrm{Si}_{2}$ phase with a cubic lattice, where $90 \%$ of $\mathrm{Mn}$ atoms can be substituted by $\mathrm{Fe}$ and $\mathrm{Cr}$ atoms, with a final $\alpha-\mathrm{Al}_{15}(\mathrm{Fe}, \mathrm{Mn}, \mathrm{Cr})_{3} \mathrm{Si}_{2}$ stoichiometry.

The chemical composition of the star-like and skeleton-like phases was supported by EDX point analysis, the results of which are documented in the Fig. 7 and Fig. 8.

Tab. 2 Content of Fe, Mn and Cr in the castings (wt. \%) and their resulting sludge factor $(S F)$ according to equation SF (3)

\begin{tabular}{|l|l|l|l|l|l|}
\hline & $\mathrm{Fe}$ & $\mathrm{Mn}$ & $\mathrm{Cr}$ & $\mathrm{SF}$ & $\mathrm{Fe} / \mathrm{Mn}$ \\
\hline Alloy CPA & 0.692 & 0.245 & 0.023 & 1.25 & 2.824 \\
\hline Alloy CPB & 1.045 & 0.320 & 0.095 & 1.97 & 3.265 \\
\hline
\end{tabular}

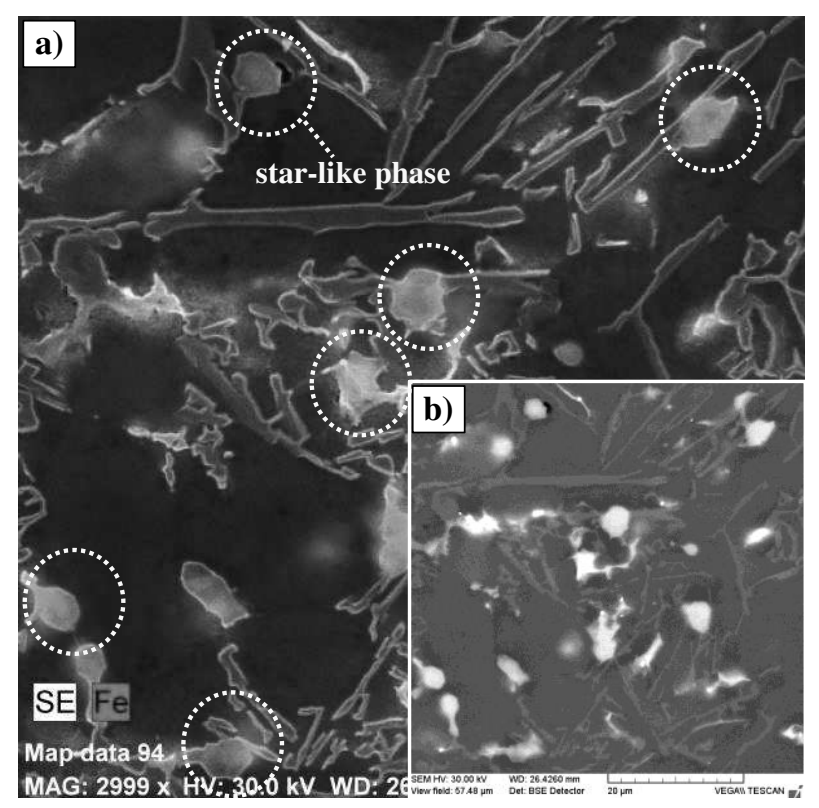

Fig. 6 Microstructure of CPB casting, SEM: a) detail of Fe-phases, EDX-mapping, etch. Dix-Keller; b) distribution of Fe-phases, BSE

The results of the EDX analysis confirmed the assumption that the star-like phases are $\mathrm{Fe} / \mathrm{Mn} / \mathrm{Cr}$ based (Fig. 7), while the skeleton-like phases are $\mathrm{Mn}$ and $\mathrm{Fe}$ based (Fig. 8).

The higher amount of star-like particles in casting $\mathrm{CPB}$ is in accordance with the results of the sludge factor calculation (Table 2). Increasing the SF leads to an overall increase in the area fraction of sludge particles, as represented in Fig. 6. In the base casting CPA, corresponding to the lowest SF (1.25), sludge particles cover only $3 \%$ of the total area, while in casting $\mathrm{CPB}$, characterized by the maximum SF (1.97), sludge area (the maximum fraction) is $40.4 \%$. It is also interesting to note that the sludge area is related to the $\mathrm{Fe} / \mathrm{Mn}$ ratio: the higher Fe/ $\mathrm{Mn}$ ratio, the higher is the sludge area.

Brinell hardness results showed that a CPB casting containing a higher percentage of sludge phases had a higher hardness (83 HBW). A hardness of approx. 74 HBW was measured in the CPA casting.

Porosity also affects the wear of the cutting tool. Alloys with tendency to form more porosity have poorer machinability because porosity interrupts cutting and can decrease tool life and/or make it difficult to drill straight 
holes. The evaluation of the microstructure shows, that casting CPB, which has a higher proportion of sludge phases, also has a significantly higher porosity; probably due to the higher iron content in this alloy.

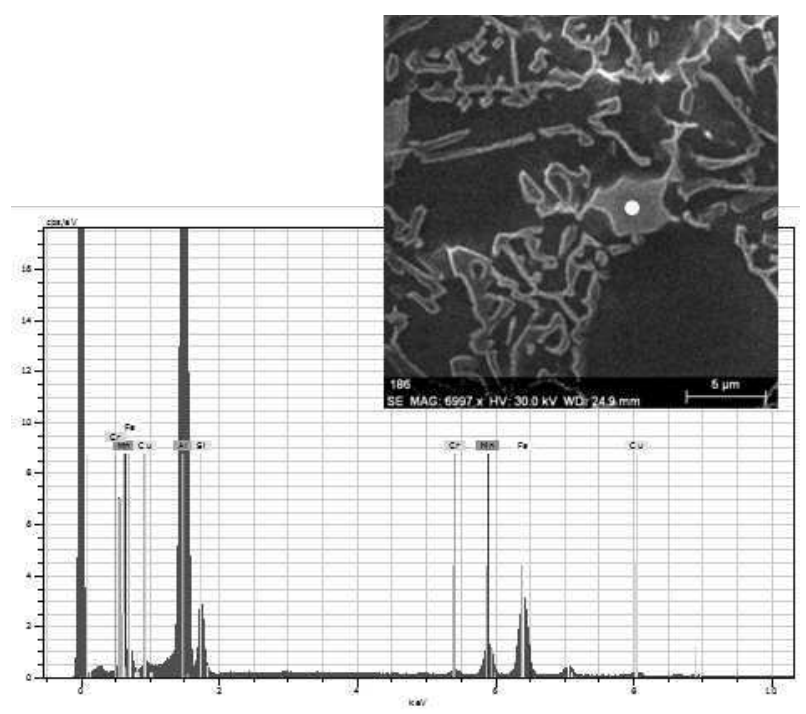

Fig. 7 SEM image and EDX result (spectrum) of starlike sludge phase

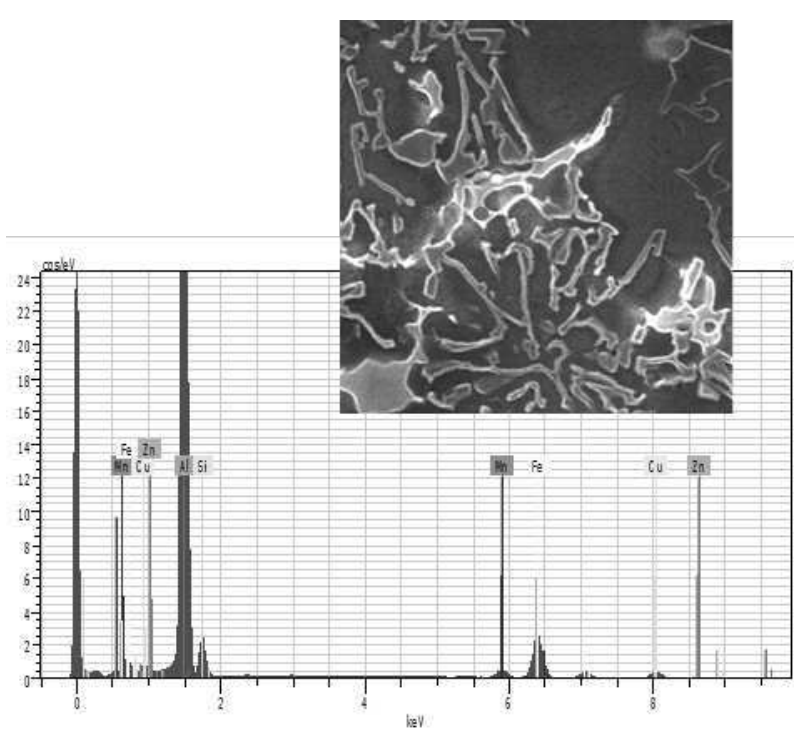

Fig. 8 SEM image and EDX result (spectrum) of skeleton/Chinese script-like phase

\section{Summary}

Analyzed was the microstructure of castings CPA and CPB made from secondary recycled AlSi12Cu1 alloy. On the basis of the experimental results the following conclusions can be stated:

- The results of the chemical composition of casting CPB (Table 1 and Table 2) indicate that AlSi12Cu1 $(\mathrm{Fe})$ alloy, which has a higher amount of iron (max. 0.95), was probably used for the production of this casting. However, the amount of manganese was lower than required by the standard for the alloy AlSi12Cu1(Fe) - (0.3 - 0.5 wt. \%) and the amount of chromium was just below the maximum allowable value.

- Increase of the $\mathrm{Fe}, \mathrm{Mn}$ and $\mathrm{Cr}$ level in casting CPB promotes the formation of larger sludge particles with a polyhedral and star-like morphology. A large number of plate/needle-like Fe-phases $\left(\mathrm{Al}_{5} \mathrm{FeSi}\right)$ was observed too.

- $\quad \mathrm{CPB}$ casting containing larger and thicker Si-particles, more Fe-sludge phases and needle-like $\mathrm{Al}_{5} \mathrm{FeSi}$ phases has a higher hardness and higher porosity was observed too.

- The calculated SF factor (1.97) was higher than the recommended value $(1.7-1.8)$ in the $\mathrm{CPB}$ casting. A higher sludge factor promotes a higher sludge formation.

The results of the metallographic evaluation of both castings show that the new supplier used a similar alloy, but with a higher iron content. Probably non-compliance with the chemical composition EN Standard (higher wt. $\%$ of $\mathrm{Fe}$, higher wt. \% of $\mathrm{Cr}$ and lower wt. \% of $\mathrm{Mn}$ ) caused the occurrence of hard sludge phases. All these factors such as thicker silicon, hard sludge phases, hard and brittle $\mathrm{Al}_{5} \mathrm{FeSi}$ phases, higher porosity can all contribute considerably to faster wear of cutting tools in the machining process.

\section{Acknowledgement}

This study has been supported by the Scientific Grant Agency of the Ministry of Education, Science and Sports of the Slovak Republic - projects: VEGA 01/0398/19, KEGA 049ŽU-4/2014 and KEGA 012ŽU4/2019. The authors would like to thank Mrs. Anna Macúchová for preparation of metallographic samples. This work was supported under the project of Operational Program Research and Innovation: Research and development activities of the University of Zilina in the Industry of 21st century in the field of materials and nanotechnologies, No. 313011T426. The project is co-funding by European Regional Development Fund.

\section{References}

[1] SCHLESINGER, E. M. (2014). Aluminium Recycling, second ed., CRC Press.

[2] KUCHARIKOVÁ, L., TILLOVÁ, E., BOKU゚VKA, O. (2016). Recycling and properties of recycled aluminium alloys used in the transportation industry. In: Transport problems, Vol. 11, No. 2, pp. 117-122.

[3] TSUSHIMA, K., SHIODA, M., SAYASHI, M., KITAOKA, S. et al. (1999). Development of a Wear Resistant Aluminum Alloy for Automotive Components. In: SAE Technical Paper, 1999-010350, https://doi.org/10.4271/1999-01-0350. 
[4] FERRARO, S. (2014). Influence of trace elements on secondary die-cast. Doctoral thesis. Università degli Studi di Padova.

[5] http://recycling.world-aluminium.org/review/recycling-indicators/

[6] TIllovÁ, E., CHALUPOVÁ, M. (2009). Structural analysis (Štruktúrna analýza), EDIS Žilina (in Slovak).

[7] EBHOTA, W.S., JEN, T.CH. Intermetallics Formation and Their Effect on Mechanical Properties of Al-Si-X Alloys. Chapter. 2. Intermetallic Compounds - Formation and Applications. pp. 21-41. INTECH. http://dx.doi.org/10.5772/intechopen.73188

[8] GAO, T., WU,Y., LI, CH., LIU, X. (2013). Morphologies and growth mechanisms of $\alpha$ $\mathrm{Al}(\mathrm{FeMn}) \mathrm{Si}$ in Al-Si-Fe-Mn alloy. In: Materials Letters, Vol. 110, pp. 191-194.

[9] SHABESTARI, S. G. (2004). The effect of iron and manganese on the formation of intermetallic compounds in aluminum-silicon alloys. In: Materials Science and Engineering A, Vol. 383, pp. 289-298.

[10] TAYLOR, J. A. (2004). The effect of iron in AlSi casting alloys. In: 35 th Australian Foundry Institute National Conference, pp. 148-157, Adelaide, South Australia.

[11] SEIFEDDINE, S. (2007). The influence of Fe on the microstructure and mechanical properties of cast Al-Si alloys. In. Literature review - Vilmer project. Jönköping University, Sweden.

[12] TILlOVÁ, E., CHALUPOVÁ, M., HURTALOVÁ, L. (2011). Evolution of phases in a recycled Al-Si cast alloy during solution treatment. Chapter 21: The Scaning Electron Microscopy. Book edited by: Dr. Viacheslav Kazmiruk, pp. 411 - 438, INTECH.

[13] FERRARO, S., BJURENSTEDT, A., SEIFEDDINE, S. (2015). On the Formation of Sludge Intermetallic Particles in Secondary Aluminum Alloys. In: Metalurgical and Materials Transactions A., Vol. 46A, pp. 3713-3722. DOI: 10.1007/s11661-015-2942-0.

[14] CESCHINI, L., MORRI, A., TOSCHI, S., BJURENSTEDT, A., SEIFEDDINE, S. (2018). Influence of Sludge Particles on the Fatigue Behavior of Al-Si-Cu Secondary Aluminium Casting Alloys. In: Metals, 8, 268; doi:10.3390/met8040268
[15] BOLIBRUCHOVÁ, D., BRŮNA, M. (2017). Impact of the Elements Affecting the Negative IronBased Phases Morphology in Aluminium Alloys Summary Results. In: Manufacturing Technology, Vol. 17, 5, pp. 675-679.

[16] BOLIBRUCHOVÁ, D., PODPROCKÁ, R., PASTIRČÁK, R., MAJOR-GABRYŠ, K. (2018). The role of $\mathrm{Mn}$ in aluminium alloys with a higher iron content. In: Archives of metallurgy and materials, Vol. 63, 4, pp. 1883-1888.

[17] DUNN, R. (1965). Aluminum Melting Problems and Their Influence on Furnace Selection. In: Die Casting Engineer, Vol. 9, pp. 8-30.

[18] GOBRECHT, J. (1975). Schwere seigerungen von Eisen, Mangan und Chrom in Aluminium-Silicium-Gußlegierungen. In: Giesserei, Vol. 62, 10, pp. 263-266.

[19] JORSTAD, J.L. (1986). Understanding Sludge. In: Die Casting Engineer, Vol. 11-12, pp. 30-36.

[20] ŠERÁK, J., VOJTECH, D. (2017). Dispersion of Mechanical Properties of Commercial Aluminum Alloys within Their Material Standards. In: Manufacturing Technology, Vol. 17, 5, pp. 831-837.

[21] Standard EN 1706:2010, Aluminium and aluminium alloys - Castings - Chemical composition and mechanical properties, (2010).

[22] TILLOVÁ, E., CHALUPOVÁ, M., KUCHARIKOVÁ, L., ZÁVODSKÁ, D., BELAN, J., VAŠKO, A. (2016). Use of Microscopy in the Study of Self-Hardening Al-Alloy for Automotive Application. In: Manufacturing Technology, Vol. 16, 5, pp. 1174-1179.

[23] VAŠKO, A., SKOČOVSKÝ, P. (2007). Kvantitatívne hodnotenie štruktúry liatin. EDIS Žilina (in Slovak).

[24] KUCHARIKOVÁ, L., TILLOVÁ, E., BELAN, J., VAŠKO, A., ŠVECOVÁ, I. (2017). Quantitative assessment of aluminium cast alloys' structural parameters to optimize its properties. In: Metalurgija/Metallurgy, Vol. 56, 1-2, pp. 145-148.

[25] ABOUEI, V., SAGHAFIAN, H., SHABESTARI, S.G., ZARGHAMI, M. (2010). Effect of Fe-rich intermetallics on the wear behavior of eutectic AlSi piston alloy (LM13). In: Materials and Design, Vol. 31, pp. 3518-3524.

[26] MONDOLFO, L. F. (1976). Aluminium alloys: structure and properties. Butterworths \& Co. Ltd. 